\title{
PENGARUH EXPERIENTIAL MARKETING TERHADAP LOYALITAS KONSUMEN STORE BERRYBENKA DI KOTA JAMBI
}

\author{
Ahmad Soleh ${ }^{1}$ \\ Dosen Tetap Universitas Muhammadiyah Jambi ${ }^{1}$ \\ ahmad.soleh@umjambi.ac.id \\ Ermaini $^{2}$ \\ Dosen Tetap Universitas Muhammadiyah Jambi ${ }^{2}$ \\ ermaini@umjambi.ac.id \\ Prima Audia Daniel ${ }^{3}$ \\ Dosen Tetap Universitas Muhammadiyah Jambi ${ }^{4}$ \\ primaaudia@ymail.com \\ Siska paramitha ${ }^{5}$ \\ Mahasiswa Universitas Muhammadiyah Jambi ${ }^{6}$
}

\section{ABSTRAK}

Penelitian yang berjudul "Pengaruh Experiantial Marketing terhadap Loyalitas Konsumen Store Berrybenka di Kota Jambi” bertujuan untuk mengetahui dan menganalisis : (1) Pengaruh experiental marketing terhadap loyalitas konsumen Store berrybenka di Kota Jambi; (2) Variable mana dari experiantal marketing yang paling berpengaruh terhadap loyalitas konsumen Store berrybenka di Kota jambi.

Metode analisis yang digunakan dalam penelitian ini adalah Explanatory (penjelasan) dengan pendekatan kuantitatif menggunakan sumber data primer dan sekunder. Dari hasil analisis menunjukkan pengujian secara serempak (simultan) semua variable experiential berpengaruh positif dan signifikan terhadap loyalitas konsumen Store Berrybenka di Kota Jambi; Sedangkan dalam pengujian secara parsial, feel yang merupakan salah satu variable experiential marketing tidak berpengaruh signifikan terhadap loyalitas konsumen Store Berrybenka di Kota Jambi; dalam pengujian secara parsial menunjukkan bahwa salah satu variable experiential marketing yaitu think memberikan pengaruh yang dominan terhadap pembelian sebesar 10,9\% dari bertambahnya pengetahuan konsumen terhadap Berrybenka (limited edition, unik, kualitas baik).

Kata Kunci: Experiantial Marketing, Loyalitas Konsumen,

\section{PENDAHULUAN}

Pesatnya perkembangan bisnis saat ini tidak lepas dari pertumbuhan ekonomi di berbagai bidang, sehingga menimbulkan persaingan yang cukup ketat. Salah satu aspek penting yang perlu dipertimbangkan dalam upaya meningkatkan penjualan adalah aspek pamasaran. Menurut Kotler dan keller (2007) "Pemasaran adalah proses perencanaan dan pelaksanaan konsepsi, penetapan harga, promosi dan pendistribusian gagasan, barang dan jasa untuk menciptakan pertukaran yang mampu memenuhi tujuan individu dan organisasi.

Experiantial marketing merupakan konsep pemasaran yang memberikan pengalaman unik, positif, dan mengesankan kepada para konsumen. Dengan hal tersebut akan memberikan 
kesan dan pengalaman bagi konsumen selama menggunakan produk. Sehingga nantinya konsumen tidak hanya akan loyal tetapi juga menyebarkan informasi mengenai produk perusahaan secara Word of Mouth.

Inti dari experiential marketing adalah untuk membangun hubungan yang langgeng dengan pelanggan. Hal ini juga diperkuat pendapat (Scmitt dalam Hermawan Kertajaya 2006) dimana experiential marketing dapat dihadirkan melalui lima unsur yaitu sense, feel, think, act, dan relate. Dengan demikian experiential marketing harus dipastikan mampu memberikan hubungan yang signifikan dengan loyalitas konsumen.

Berrybenka merupakan salah satu jenis usaha yang bergerak dalam bidang fashion wanita yang berupa pakaian, sepatu, tas dan aksesoris terkini dengan kualitas dan bentuk yang unik. Berrybenka pertama kali dikenal melalui website www.berrybenka.com dan salah satu ritel fashion berbasis teknologi terbesar di Indonesia yang mulai serius menggarap strategi online to offline $(\mathrm{O} 2 \mathrm{O})$.

Store Berrybenka pertama di Kota Jambi opening pada Oktober 2020 dan tercatat mengalami penaikan dan penurunan konsumen pada periode September 2020 - Agustus 2021 dengan target minimal 500 konsumen perbulannya. Hal ini mungkin disebabkan oleh banyaknya pesaing dengan jenis fashion yang hampir sama dan harga yang lebih terjangkau. Disini terlihat masalah yang dihadapi oleh strore Berrybenka jambi adalah kurangnya loyalitas jangka Panjang dan kurangnya pemahaman masyarakat Kota Jambi dengan merek dan produk Berrybenka.

Memilih Berrybenka dalam menguji experiential marketing terhadap loyalitasnya, karena Berrybenka adalah Brand Lokal dengan barang rasa internasional dimana produk-produknya pun beragam dan harganya pun bervariasi untuk semua kalangan. Experiantial marketing bertujuan untuk meningkatkan loyalitas jangka Panjang dan juga mengikat konsumen dengan memberikan pengalaman yang tak terlupakan Ketika menikmati dari perusahaan tersebut (Nehamia, 2010) dan (Soleh. Dkk 2019). Berdasarkan uraian diatas maka penelitian ini bertujuan untuk menganalisis: (1) Pengaruh experiental marketing terhadap loyalitas konsumen Store berrybenka di Kota Jambi; (2) Variable mana dari experiantal marketing yang paling berpengaruh terhadap loyalitas konsumen Store berrybenka di Kota jambi. Dengan menggunakan 5 dimensi experiential marketing yakni Daya Tarik (Sense), Perasaan (Feel), Ekspetasi (Think), Perilaku (Act), dan Pertalian (Relate) 


\section{TINJAUAN PUSTAKA}

\section{Experiantial marketing}

Menurut Leaderman (2006) Experiantial marketing adalah suatu metodologi atau konsep pemasaran yang bergerak dari cara pemasar yang sebelumnya tradisional baik dalam hal ciriciri ataupun keuntungannya konsumen dengan cara personal dan mengesankan yang dapat menjembatani antara permintaan konsumen yang meningkat dengna ajakan pemasar dna mereknya sesuai dengan produknya, dan untuk mengatasi lambatnya Langkah pemasar tradisional untuk segera meninggalkan pemasar melalui media masa yang hanya satu arah.

\section{Loyalitas pelanggan}

Menurut Kotler dan Keller (2009) loyalitas adalah komitmen yang dipegang secara mendalam untuk membeli atau mendukung kembali produk atau jasa yang disukai di masa depan mesi pengaruh situasi dan usaha pemasaran berpotensi menyebabkan pelanggan beralih.

\section{Pengertian pemasaran}

Menurut William J. Stantion (2012) menyatakan bahwa "Pemasaran adalah sistem keseluruhan dari berbagai kegiatan bisnis atau usaha yang ditujukan untuk merencanakan, menentukan harga barang atau jasa, mempromosikannya, dan mendistribusikannya kepada konsumen dan bisa memuaskan konsumen".

\section{Pengertian manajemen pamasaran}

Menurut Sumarni (Sunyoto, 2014) manajemen pemasaran adalah analisis, perencanaan, pelaksanaan, dan pengendalian atas program yang dirancang untuk menciptakan, membentuk, dan mempertahankan pertukaran yang menguntungkan dengan pembeli sasaran organisasi.

\section{Pengertian produk}

Produk didefinisikan oleh Kotler dalam buku H. Abdul Manaf (2016) mengemukakan produk yaitu $A$ product is anything that can be offered to a market to satisfy a want or need. Product that are marketed include physical good, sevices, events, persons, pleace, properties, organization, information and ideas, yang artinya produk adalah segala sesuatu yang dapa ditawarkan di pasar, untuk memuaskan kebutuhan dan keinginan konsumen. Produk terdiri atas barang, jasa, pengalaman, events, orang, tempat, kepemilikan, oraganisasi, informasi, dan ide. 


\section{Pengertian loyalitas}

Loyalitas dinyatakan sebagai suatu perilaku yang diharapkan atas produk / layanan yang meliputi kemungkinan pembelian lebih lanjut/perubahan perjanjian layanan, atau sebaliknya seberapa besar kemungkinan pelanggan akan beralih keapda merek lain (Ibrahim, 2009)

\section{METODOLOGI}

Metode analisis dalam penelitian ini adalah Explanatory (penjelasan) dengan pendekatan kuantitaf. Yaitu penelitian yang bermaksud menjelaskan kedukukan variabel-variabel yang di teliti serta berhubungan antara satu variabel dan variable lainnya (Sugiyono, 2011).

\section{Sumber data}

Data yang digunakan dalam penelitian ini adalah Primer dan sekunder. Data primer diperoleh dari respondent yang memenuhi syarat, data tersebut adalah hasil jawaban pengisian kuisioner dari responden yang memenuhi kriteria responden representative (mewakili), yaitu hasil wawancara dan penyebaran kuisioner. Dalam penelitian ini data primer diperoleh dari pembagian kuesioner secara online maupun ofline terhadap pelanggan Store Berrybenka di Kota Jambi. Data sekunder dalam penelitian ini bersumber dari data penelitian sebelumnya dengan menggunakan literature yang terkait dengan penelitian. Data sekunder in diguanakan untuk memperkuat penemuan dan melengkapi informasi yang telah dikumpulkan.

\section{Populasi dan sampel}

Populasi dalam penelitian ini adalah pelanggan Berrybenka di Kota Jambi.Sampel penelitian menurut Arikunto (2010) adalah sebaigan populasi yang akan diteliti dan dapat mewakili seluruhnya.

Dalam penelitian ini penulis menggunakan metode slovin untuk mengetahui jumlah yang akan diteliti. Cara menentukan sampel dengan menggunakan metode slovin sebagai berikut:

$$
\mathrm{n}=\frac{N}{1+n e^{2}}
$$

Keterangan:

$n=$ Jumlah Sampel

$\mathrm{N}=$ Jumlah Populasi

$\mathrm{e}=$ Persen Kelonggaran $5 \%$

$1=$ Konstanta 
Dari hasil perhitungan tersebut diperoleh dari sebesar 380,78 orang dan dibulatkan menjadi 400 orang. Untuk mempermudah perhitungan dan mendapatkan data yang lebih akurat, sehingga sampel dalam penelitian ini sebanyak 374 orang dengan menggunakan Teknik purposive sampling, yaitu penentuan sampel dengan kriteria tertentu (Sugiyono, 2016).

\section{Uji instrumen penelitian}

\section{Uji validitas}

Uji validitas digunakan untuk mengukur sah atau valid tidaknya sautu kuesioner. Suatu kuesioner dikatakan valid jika pertanyaan pada kuisioner mampu mengungkapkan sesuatu yang akan diukur oleh kuesioner tersebut (Ghozali, 2012). Validitas yang digunakan dalam penelitian ini (content validity) yaitu menggambarkan keseseuaian sebauah pengukur data dengan apa yang akan diukur. Dasar pengambilan keputusan untuk menguji validitas butir angket adalah:

- Jika $\mathrm{r}$ hitung positif dan $\mathrm{r}$ hitung $>\mathrm{r}$ table maka variable tersebut valid.

- Jika $\mathrm{r}$ hitung tidak positif serta $\mathrm{r}$ hitung $<\mathrm{r}$ table maka variable tersebut tidak valid.

\section{Uji realibilitas}

Uji Reliabilitas adalah alat untuk mengukur suatu kuesioner yang merupakan indicator dari variable atau konstruk. Suatu kuesioner dikatakan reliabel atau handal jika jawaban seseorang terhadap pernyataan adalah konsisten atau stabil dari waktu ke waktu (Ghozali, 2012). Penelitian ini menggunakan teknik reabilitas interbal consistency yang merupakan suatu pengujian yang dilakukan dengan mencobakan instrument sekali saja dan dari data yang diperoleh dianalisis degan tertentu.

\section{Uji hipotesis}

\section{Analisis regresi berganda}

Menurut Sugiyono (2016) Analisis regresi berganda digunakan oleh peneliti, apabila peneliti meramalkan bagaiamana naik turunnya keadaan variable dependen apabila dua atau lebih variable independent sebagai factor predictor dimanipulasi (dinaik turunkan nilainya). Jadi analisis regresi berganda akan dilakukan apabila variable inedpenden minimal 2. Untuk menyelesaikan rurmusan masalah yang petama maka digunakan rumus regresi berganda. Persamaan regresinya adalah: 


$$
Y=\alpha_{0}+\beta_{1} X_{1}+\beta_{2} X_{2}+\beta_{3} X_{3}+\beta_{4} X_{4}+\beta_{5} X_{5}+e
$$

Keterangan:

$\begin{array}{ll}\mathrm{Y} & : \text { Loyalitas } \\ & : \text { Konstanta } \\ & : \text { Koefesien Regresi } \\ \mathrm{X} 1 & : \text { Daya tarik ( Sense ) } \\ \mathrm{X} 2 & : \text { Perasaan ( Feel ) } \\ \mathrm{X} 3 & : \text { Ekspetasi ( Think ) } \\ \mathrm{X} 4 & : \text { Gaya Hidup ( Act ) } \\ \mathrm{X} 5 & : \text { Budaya/Style ( Relate ) }\end{array}$

\section{Uji T}

Uji t digunakan untuk menguji signifikan hubungan antar variable $\mathrm{X}$ dan variabel $\mathrm{Y}$ secara parsial atau dapat dikatakan uji t pada dasarnya menunjukan seberap jauh satu bariabel independent secara individual dalam menerangkan variasi-variasi dependen (Ghozali, 2012).

Uji t berarti melakukan pengujian terhadap koefisien regresi secara parsial. Pengujian ini dilakukan untuk mengetahui signifikansi peran secara parsial antara variable independen terhadap variable dependen dengan mengasumsikan bahwa variable independent lain dianggap konstan. (Sugiyono, 2016)

Merumuskan uji t sebagai berikut :

Keterangan: $\mathrm{t}=$ distribusi $\mathrm{t}$

$$
\begin{aligned}
& \mathrm{N}=\text { jumlah data } \\
& \mathrm{R}=\text { koefesien korelasi parsial } \\
& \mathrm{R} 2=\text { koefesien determinasi }
\end{aligned}
$$

$\mathrm{T}$ hasil perhitungna ini selanjutnya dibandingkan dengan $\mathrm{t}$ table dengan menggunakan tingkat kesalaha 0,05 . Kriteria yang digunakan sebagai desar perbandiangna sebagai berikut:

Ha diterima jika nilai $-\mathrm{t}$ table $<\mathrm{t}$ hitung $<\mathrm{t}$ table

Ho ditolak jika nilai $\mathrm{t}$ hitung $>\mathrm{t}$ table atau $\mathrm{t}$ hitung $<-\mathrm{t}$ table

Bila terjadi penerimaan Ho maka dapat disimpulkan suatu pengaruh adalah tidak signifikan, ssedangkan bila Ho ditolak artinya sautu pengaruh signifikan.

\section{Uji F}

Untuk menguji hipotesis ini digunakan statistic F dengan kriteria pengambila keputusan sebagai berikut: 
1. Dengan membandingkan nilai $\mathrm{F}$ table dengan $\mathrm{F}$ hitung

Apabila Ftabel $>$ Fhitung, maka Ho diterima dan Ha ditolak, Apabila Ftabel < Fhitung, maka Ho ditolak dan Ha diterima.

2. Dengan menggunakan angka probabilitas signifikansi

Apabila probabilitas signifikansi $>0,005$, maka Ho diterima dan Ha ditolak, jika probabilitas signifikansi < 0,05, maka Ho ditolak dan Ha diterima (Ghozali, 2012).

Adapun langkah-langkah pengujian hipotesis tersebut adalah :

a. Menentukan F hitung berdasarkan hasil outuput analisis regresi.

b. Tingkat signifikansi $(\alpha)$ 0,05 atau 5\% untuk menguji apakah hipotesis yang diajukan dalam penelitian ini diterima atau ditolak.

Adanya alternative lain untuk menerima dan menolak hipotesis ini dengan melihat signifikansinya (p-value). Apabila tingkat signifikansinya lebih kecil dari a yang ltelah ditentukan yaitu 0,05 maka Ha diterima, secara bersama-sama semua variable bebas berpengaruh secara signifikan terhadap variable terkait, sebaliknya apabila tingkat signifikansi F lebih besar dari $\alpha=0,05$ maka Ho diterima artinya Bersama- sama terhadap variabel terikat.

\section{Analisis koefisien determinasi $\left(\mathbf{R}^{2}\right)$}

Analisis koefisien determinasi disesuaikan dan digunakan untuk mengetahui seberap besar presentase variabel indpenden $(\mathrm{X})$ terhadap $(\mathrm{Y})$ dalam bentuk presentase. Untuk regresi yang menggunakan 4 atau lebih variabel independent menggunakan koefisien determinasi adjusted R square. ( Priyanto, 2010).

Besarnya $\mathrm{r}^{\wedge} 2$ berada diantar 0 (nol) dan 1 (satu) yaitu $0 \leq \mathrm{r}^{\wedge} 2 \leq 1$. Jika nilai $\mathrm{r}^{\wedge} 2$ semakin mendekati 1 (satu) maka model tersebut baik dan pengaruh antar variabel bebas X dengan variabel Y semakin kuat (erat hubungannya).

\section{Definisi operasional dan operasional variabel}

\section{Definisi operasional}

Definisi operasional varibel adalah unsur penelitian yang memberitahukan bagaimana caranya mengukur suatu variabel. Dalam penelitian ini definisi variabel yang diteliti adalah:

1. Variabel bebas adalah varaibel yang mempengaruhi variabel terikat baik secara positif atau negatif. Variabel bebas dalam penelitian ini adalah: experiential marketing (x), terdiri dari sense (1), feel (2), think (3), act (4), dan relate (5). 
2. Variabel terikat adalah variabel yang dipengaruhi oleh variabel oleh variabel bebas. Dalam penelitian ini variabel yang terikat adalah loyalitas (y).

\section{Operasional variabel}

Tabel 1.

Operasional variabel

\begin{tabular}{|c|c|c|c|c|}
\hline $\begin{array}{c}\text { Variabel } \\
\text { Penelitian }\end{array}$ & Definisi & Sub Variabel & Indikator & Skala \\
\hline \multirow[t]{5}{*}{$\begin{array}{l}\text { Experiantial } \\
\text { Marketing } \\
\text { (x) }\end{array}$} & \multirow{5}{*}{$\begin{array}{lr}\text { Menurut } & \text { Schmitt } \\
(2005) & \text { Experiential } \\
\text { marketing } \text { merupakan } \\
\text { promosi yang dapat } \\
\text { dilakukan perusahaan } \\
\text { sehingga merangsang } \\
\text { pelanggan } & \text { untuk } \\
\text { membeli dan melalukan } \\
\text { pembelian r ulang. } \\
\text { Experiential marketing } \\
\text { adalah } \\
\text { pendekatan sebauh } \\
\text { membeirkan informasi } \\
\text { yang leibh dari sekedar } \\
\text { informasi mengenai } \\
\text { sebuah produk. }\end{array}$} & 1.Sense (X1) & $\begin{array}{l}\text { 1.Model yang unik } \\
\text { 2.Bahan yang } \\
\text { berkualitas } \\
\text { 3.Pilihan warna } \\
\text { yang menarik. }\end{array}$ & Ordianal \\
\hline & & 2.Feel (X2) & $\begin{array}{l}\text { 1. Jaminan kualitas } \\
\text { 2. Pelayanan terbaik } \\
\text { 3. Merek yang } \\
\text { sudah terkenal }\end{array}$ & \\
\hline & & 3.Think (X3) & $\begin{array}{ll}\text { 1. Informasi } & \text { harga } \\
\text { lengkap dna benar } \\
\text { 2.Harga } & \text { sesuai } \\
\text { kualitas } & \\
\text { 3. Barang } & \text { Limited } \\
\text { Edition } & \\
\end{array}$ & \\
\hline & & 4.Act (X4) & $\begin{array}{l}\text { 1.Produk terpercaya } \\
\text { 2.Trend dikalangan } \\
\text { masyarakat } \\
\text { 3.Fashion terupdate }\end{array}$ & \\
\hline & & 5.Relate (X5) & $\begin{array}{l}\text { 1.Banyak } \\
\text { pengalaman positif } \\
\text { 2.Banyak promosi } \\
\text { WOM dari pihak } \\
\text { lain. } \\
\text { 3.Adanya jaminan } \\
\text { mutu produk }\end{array}$ & \\
\hline Loyalitas & $\begin{array}{lr}\text { Menurut } & \text { (Tjiptono, } \\
387: 2001) & \text { Loyalitas } \\
\text { situasi dimana } & \text { konsumen bersikap } \\
\text { positif terhadap produk/ } \\
\text { produsen dan disertai } \\
\text { pola pembelian ulang } \\
\text { yang konsisten }\end{array}$ & & $\begin{array}{l}\text { 1.Melakukan } \\
\text { pemblian berulang } \\
\text { 2.Mereferensikan } \\
\text { kepada orang lain } \\
\text { 3.Menunjukan } \\
\text { kekebalan terhadap } \\
\text { pesaing }\end{array}$ & \\
\hline
\end{tabular}

\section{HASIL}

Instrumen yang digunakan dalam penelitian ini adalah daftar pertanyaan (kuesionaer). Analisis deskriptif pada penelitian in diperoleh dari penyebaran kuesioner sebanyak 400 
responden di kalangan masyarakat. Karakteristik responden dalam penelitian ini adala berdasarkan jenis kelamin, Pendidikan, pekerjaan, dan lama pembelian di Store Berrybenka.

\section{Karakteristik responden berdasarkan jenis kelamin}

Tabel berikut ini memperlihatkan data pengunjung Store Berrybenka di Kota Jambi yang menjadi sampel penelitian:

Tabel 2

Karakteristik responden berdasarkan jenis Kelamin

\begin{tabular}{|c|c|c|}
\hline Jenis Kelamin & Jumlah & Persentase (\%) \\
\hline Pria & 9 & $2,4 \%$ \\
\hline Wanita & 391 & $97,6 \%$ \\
\hline Total & 400 & $100 \%$ \\
\hline
\end{tabular}

Sumber :Data diolah, 2021

Tabel 2 menunjukkan karakteristik responden berdasarkan jenis kelamin dikelompokkan menjadi Pria dan Wanita. Dari hasil pengolahan data yang telah dilakukan maka dapat diketahui bahwa 9 orang atau 2,4\% responden adalah Pria dan 391 orang atau 97,6 \% adalah Wanita. Dari data ini dapat disimpulkan bahwa responden didominasi oleh jenis kelamin Wanita sebanyak $97,6 \%$.

\section{Karakteristik responden berdasarkan pendidikan}

Tabel berikut ini memperlihatkan Pendidikan terakhir pengunjung Store Berrybenka di Kota Jambi yang menjadi sampel penelitian:

Tabel 3

Karakteristik Responden berdasarkan Pendidikan terakhir

\begin{tabular}{|c|c|c|}
\hline Pendidikan & Jumlah & Persentase(\%) \\
\hline SMA & 40 & $10,8 \%$ \\
\hline D3 & 21 & $4,6 \%$ \\
\hline S1 & 254 & $64,4 \%$ \\
\hline S2 & 85 & $20,2 \%$ \\
\hline Total & 400 & $100 \%$ \\
\hline
\end{tabular}

Sumber : Data diolah, 2021 
Tabel 3 menunjukkan bahwa Pendidikan S1 menjadi Pendidikan terbanyak dalam penelitian ini yaitu sebanyak 254 orang responden $(64,4 \%), 40$ orang reseponden $(10,8 \%)$ Pendidikan SMA, 21 orang responden (4,6\%) penididikan D3 dna 85 orang responden $(20,2 \%)$ Pendidikan S2. Hal in berarti bahwa responden didominasi oleh Pendidikan S1.

\section{Karakteristik responden berdasarkan pekerjaan.}

Tabel berikut ini memperlihatkan Pekerjaan pengunjung Store Berrybenka di Kota Jambi yang menjadi sampel penelitian:

Tabel 4

Karakteristik responden berdasarkan pekerjaan

\begin{tabular}{|c|c|c|}
\hline Pekerjaan & Jumlah & Persentase \\
\hline Mahasiswa & 119 & $31,6 \%$ \\
\hline Wiraswasta & 201 & $50,9 \%$ \\
\hline PNS & 75 & $16,4 \%$ \\
\hline Tidak Bekerja & 5 & $1,1 \%$ \\
\hline Total & 400 & $100 \%$ \\
\hline
\end{tabular}

Sumber : Data diolah, 2021

Tabel 4 menunjukan bahwa pekerjaan Wiraswasta menjadi pekerjaan terbanyak dalam penelitian ini yaitu sebanyak 201 orang responden $(50,9 \%), 119$ orang responden $(31,6 \%)$ pekerjaan Pelajar, 75 orang responden $(61,4 \%)$ pekerjaan PNS dan 5 orang responden $(1,1 \%)$. Hal ini berarti bahwa responden didominasi oleh pekerjaan Wiraswasta.

\section{Karakteristik responden berdasarkan lama penggunaan}

Tabel berikut ini memperlihatkan Pekerjaan pengunjung Store Berrybenka di Kota Jambi yang menjadi sampel penelitian:

Tabel 5

Karakteristik responden berdasarkan lama pembelian

\begin{tabular}{|c|c|c|}
\hline Lama penggunaan & Jumlah & Persentase \\
\hline $1-3$ bulan & 132 & $35,5 \%$ \\
\hline $3-6$ bulan & 187 & $46,5 \%$ \\
\hline$>1$ tahun & 81 & $18 \%$ \\
\hline Total & 400 & $100 \%$ \\
\hline
\end{tabular}

Sumber : Data diolah, 2021 
Tabel 5 menunjukan bahwa lama pembelian $3-6$ bulan menjadi lama penggunaan terbanyak dalam penelitian ini yaitu sebanyak 187 orang responden (46,5\%), 132 orang responden $(35,5 \%)$ lama penggunaan 1 - 3 bulan, 81 orang responden (18\%) lama penggunaan $>1$ tahun. Hal ini berarti bahwa responden didominasi oleh lama pembelian $3-6$ bulan.

\section{Uji validitas dan uji reliabilitas}

\section{Uji validitas}

Uji validitas akan menguji masing - masing variable yang digunakan dalam penelitian ini, menampilkan hasil uji validitas terhadap 374 responden dengan menggunakan analisis faktor. Dimana keseluruhan variable penelitian memuat 18 pertanyaan yang harus dijawab oleh responden. Instrument yang valid berarti alat ukur yang digunakan untuk mnedapatkan data (mengukur) itu valid. Suatu kuesioner dikatakan valid jika pertanyaan pada kuesioner mampu untuk mengungkapkan sesuatu yang akan diikuti oleh kuesioner tersebut.

Uji signifikansi dilakukan dengan cara membandingkan nilai rhitung dengan rtabel. Adapun cara mengetahui rtabel tersebut dari degree of freedom $(\mathrm{df})=\mathrm{n}-2$, dalam hal ini $\mathrm{n}$ adalah jumlah sampel atau jumlah responden dari kuesioner yang dapat diolah yaitu sebanyak 400 orang jadi dapat dikatahui besarnya df diperoleh dari $400-2=398$, dengan df dan alpha $=$ 0,05 didapat rtabel sebesar 0,098 (dilihat rtabel pada df 398 dengan uji dua sisi). Berdasarkan analisis yang telah dilakukan, maka hasil pengujian validitas ditunjukan pada table 5.11 berikut:

\section{Tabel 6}

Hasil pengujian validitas

\begin{tabular}{|c|c|c|c|c|c|}
\hline No. & Indicator & varibel & R hitung & R table & Keterangan \\
\hline \multirow[t]{3}{*}{1.} & \multirow[t]{3}{*}{ Sense (X1) } & Bentuk model yang sangat unik & 0,519 & 0,098 & Valid \\
\hline & & Fashion yang berkualitas & 0,694 & 0,098 & Valid \\
\hline & & $\begin{array}{ll}\text { Berrybenka } & \text { menyediakan } \\
\text { banyak pilihan warna yang } \\
\text { menarik }\end{array}$ & 0,577 & 0,098 & Valid \\
\hline \multirow[t]{3}{*}{2.} & \multirow[t]{3}{*}{ Feel (X2) } & $\begin{array}{l}\text { Berrybenka fashion Jaminan } \\
\text { yang kualitas }\end{array}$ & 0,605 & 0,098 & Valid \\
\hline & & $\begin{array}{l}\text { Berrybenka mempunyai } \\
\text { pelayanan yang baik }\end{array}$ & 0,705 & 0,098 & Valid \\
\hline & & $\begin{array}{l}\text { Kualitas merek Berrybenka } \\
\text { yang sudah terkenal }\end{array}$ & 0,616 & 0,098 & Valid \\
\hline
\end{tabular}




\begin{tabular}{|c|c|c|c|c|c|}
\hline \multirow[t]{3}{*}{3} & \multirow[t]{3}{*}{ Think (X3) } & $\mathrm{C}$ & 0,626 & 0,098 & Valid \\
\hline & & $\begin{array}{l}\text { Harga Berrybenka yang sesuai } \\
\text { dengan kualitas }\end{array}$ & 0,701 & 0,098 & Valid \\
\hline & & $\begin{array}{l}\text { Barang Berrybenka } \text { Limited } \\
\text { Edition }\end{array}$ & 0,580 & 0,098 & Valid \\
\hline \multirow[t]{3}{*}{4.} & \multirow[t]{2}{*}{ Act (X4) } & $\mathrm{C}$ & 0,626 & 0,098 & Valid \\
\hline & & $\begin{array}{l}\text { Berrybenka menjadi trend } \\
\text { dikalangan masyarakat }\end{array}$ & 0,680 & 0,098 & Valid \\
\hline & & $\begin{array}{l}\text { Berrybenka fashion yang } \\
\text { terupdate }\end{array}$ & 0,579 & 0,098 & Valid \\
\hline \multirow[t]{3}{*}{5.} & \multirow[t]{3}{*}{ Relate (X5) } & $\begin{array}{l}\text { Banyak mendengar bahwa } \\
\text { pengalaman Berrybenka selalu } \\
\text { positif }\end{array}$ & 0,590 & 0,098 & Valid \\
\hline & & $\begin{array}{l}\text { Banyak promosi WOM dari } \\
\text { pihak lain }\end{array}$ & 0,654 & 0,098 & Valid \\
\hline & & Adanya jaminan mutu produk & 0,571 & 0,098 & Valid \\
\hline \multirow[t]{3}{*}{6.} & \multirow[t]{3}{*}{ Loyalitas (Y) } & $\begin{array}{l}\text { Melakukan pembelian berulang } \\
\text { secara teratur }\end{array}$ & 0,655 & 0,098 & Valid \\
\hline & & $\begin{array}{l}\text { Mereferensikan kepada orang } \\
\text { lain }\end{array}$ & 0,693 & 0,098 & Valid \\
\hline & & $\begin{array}{l}\text { Menunjukan kekebalan } \\
\text { terhadap daya Tarik pesaing }\end{array}$ & 0,649 & 0,098 & Valid \\
\hline
\end{tabular}

Sumber:Data diolah, 2021

Tabel 6 diperoleh bahwa semua indikator yang digunakan untuk mengukur variable variable yang digunakan dalam penelitian ini mempunyai korelasi yang lebih besar dari rtabel $(0,098)$ sehingga semua indikator tersebut adalah valid.

\section{Uji reliabilitas}

Pengujian reliabilitas dilakukan peneliti dengan melihat nilai Cronbach Alpha dengan bantuan computer melalui program SPSS For Windows. Dalam penelitian ini, uji reliabilitas dilakukan satu kali pengukurn saja. Suatu konstruk atau variable dikatakan reliabel jika memberikan nilai Cronbach Alpha $>0.60$ (Wahyu \& Sumintono 2013). Adapun hasil reliabilitas dalam penelitian ini dapat dilihat pada table 7 berikut: 


\section{Tabel 7}

Hasil pengujian reliabilitas

\begin{tabular}{|l|l|c|c|c|}
\hline No & Variabel & Dimensi & Cronbach & Keterangan \\
\hline 1 & Experiential & Sense & 0,683 & Reliabel \\
\cline { 3 - 5 } & \multirow{2}{*}{\begin{tabular}{l} 
Marketing \\
\cline { 3 - 5 }
\end{tabular}} & Feel & 0,637 & Reliabel \\
\cline { 3 - 5 } & & Think & 0,627 & Reliabel \\
\cline { 3 - 5 } & & Act & 0,616 & Reliabel \\
\cline { 3 - 5 } & & Relate & 0,681 & Reliabel \\
\hline 2 & Loyalitas & 0,666 & Reliabel \\
\hline
\end{tabular}

Sumber : Data diolah, 2021

Hasil tersebut menunjukan bahwa semua variable mempunyai Cronbach Alpha lebih besar dari 0,60 sehingga dapat dikatakan semua konsep pengukur masing - masing variabel dari kuestioner adalah reliable.

\section{Hasil pengujian hipotesis}

\section{Hasil analisis uji regresi linear berganda}

Pengujian hipotesis penelitian dilakukan untuk mengetahui apakah variabel independen (sense, feel, think, act, relate) dalam model regresi berpengaruh terhadap variabel dependen (loyalitas), maka dilakukan pengujian dengan menggunakan uji $\mathrm{F}$, uji $\mathrm{T}$ dan uji koefisien determasi $\left(\mathrm{R}^{2}\right)$. Berdasarkan hasil pengujian dalam menggunakan SPSS22 dengan metode regresi linear berganda maka diperoleh hasil sebagai berikut:

Tabel 8

Hasil uji koefisien regresi linear

Coefficients ${ }^{\mathrm{a}}$

\begin{tabular}{|c|c|c|c|c|c|c|}
\hline \multirow{2}{*}{\multicolumn{2}{|c|}{ Model }} & \multicolumn{2}{|c|}{ Unstandardized Coefficients } & \multirow{2}{*}{$\begin{array}{c}\begin{array}{c}\text { Standardized } \\
\text { Coefficients }\end{array} \\
\text { Beta }\end{array}$} & \multirow[b]{2}{*}{$\mathrm{t}$} & \multirow[b]{2}{*}{ Sig. } \\
\hline & & B & Std. Error & & & \\
\hline & (Constant) & 8,110 & 1,265 & & 6,411 &, 000 \\
\hline & SENSE &, 100 &, 050 & 099 & 1,990 &, 047 \\
\hline & FEEL &, 002 &, 044 & ,003 &, 054 & ,957 \\
\hline & THINK &, 109 &, 047 &, 115 & 2,301 &, 022 \\
\hline & $\mathrm{ACT}$ &, 101 &, 050 &, $10 \mathrm{~b} 1$ & 2,023 &, 044 \\
\hline & RELATE & ,122 &, 055 & ,110 & 2,210 &, 028 \\
\hline
\end{tabular}

a. Dependent Variable: LOYALITAS

Sumber: Data diolah, 2021 
Berdasarkan Tabel 8, maka persamaan Analisis Regresi Berganda untuk penelitian ini adalah :

$$
\mathrm{Y}=8,110+0,100 \mathrm{X}_{1}+0,002 \mathrm{X}_{2}+0,109 \mathrm{X}_{3}+0,101 \mathrm{X}_{4}+0,122 \mathrm{X}_{5}+\mathrm{e}
$$

Persamaan regresi di atas dapat dijelaskan sebagai berikut:

1. Konstanta sebesar 8,110 artinya jika variable independent Sense, Feel, Think, Act, dan Relate nilainya adalah 0, maka Loyalitas nilainya adalah 8,110 satuan.

2. Koefisien regresi variabel Sense sebesar 0,100; artinya jika variabel independen lain nilainya tetap dan Sense mengalami kenaikan 1 satuan, maka Loyalitas akan mengalami peningkatan sebesar 0,100 . Koefisien bernilai positif artinya terjadi hubungan positif antara Sense dengan Loyalitas, semakin naik maka semakin meningkat Loyalitas.

3. Koefisien regresi variabel Feel sebesar 0,002; artinya jika variabel independen lain nilainya tetap dan Feel mengalami kenaikan 1satuan, maka Loyalitas akan mengalami peningkatan sebesar 0,002 . Koefisien bernilai positif artinya terjadi hubungan positif antara Feel dengan Loyalitas, semakin naik maka semakin meningkat Loyalitas.

4. Koefisien regresi variabel Think sebesar 0,109; artinya jika variabel independen lain nilainya tetap dan Think mengalami kenaikan 1satuan, maka Loyalitas akan mengalami peningkatan sebesar 0,109. Koefisien bernilai positif artinya terjadi hubungan positif antara Think dengan Loyalitas, semakin naik maka semakin meningkat Loyalitas.

5. Koefisien regresi variabel Act sebesar 0,101; artinya jika variabel independen lain nilainya tetap dan Act mengalami kenaikan 1satuan, maka Loyalitas akan mengalami peningkatan sebesar 0,101 . Koefisien bernilai positif artinya terjadi hubungan positif antara Act dengan Loyalitas, semakin naik maka semakin meningkat Loyalitas.

6. Koefisien regresi variabel Relate sebesar 0,122; artinya jika variabel independen lain nilainya tetap dan Relate mengalami kenaikan 1satuan, maka Loyalitas akan mengalami peningkatan sebesar 0,122. Koefisien bernilai positif artinya terjadi hubungan positif antara Relate dengan Loyalitas, semakin naik maka semakin meningkat Loyalitas. 


\section{Pengujian hipotesis secara parsial (uji-t)}

\begin{tabular}{|c|c|c|c|c|c|c|}
\hline \multicolumn{7}{|c|}{$\begin{array}{c}\text { Tabel } 9 \\
\text { Hasil uji parsial (uji-t) } \\
\text { Coefficients }^{\text {a }}\end{array}$} \\
\hline \multirow{2}{*}{\multicolumn{2}{|c|}{ Model }} & \multicolumn{2}{|c|}{ Unstandardized Coefficients } & \multirow{2}{*}{$\begin{array}{c}\begin{array}{c}\text { Standardized } \\
\text { Coefficients }\end{array} \\
\text { Beta }\end{array}$} & \multirow[b]{2}{*}{$\mathrm{t}$} & \multirow[b]{2}{*}{ Sig. } \\
\hline & & $\mathrm{B}$ & Std. Error & & & \\
\hline & (Constant) & 8,110 & 1,265 & & 6,411 &, 000 \\
\hline & SENSE &, 100 &, 050 & ,099 & 1,990 &, 047 \\
\hline & FEEL &, 002 &, 044 &, 003 &, 054 & ,957 \\
\hline & THINK &, 109 &, 047 &, 115 & 2,301 &, 022 \\
\hline & ACT &, 101 &, 050 &, 101 & 2,023 &, 044 \\
\hline & RELATE &, 122 &, 055 &, 110 & 2,210 & ,028 \\
\hline
\end{tabular}

a. Dependent Variable: LOYALITAS

Sumber: Data diolah, 2021

Dilihat dari Tabel 9 diperoleh nilai t-hitung dari setiap variabel bebas (independent) dalam penelitian ini. Nilai t-hitung dari setiap variabel bebas (independent) akan dibandingkan dengan nilai t-tabel dengan menggunakan tingkat kepercayaan (confidence interval) $95 \%$ atau $\alpha=0,05$ dimana $\mathrm{df}=$ jumlah sampel - jumlah variabel $=400-5=394$ maka diperoleh nilai $t$-tabel 1,966

Dari hasil Uji T akan diketahui pengaruh setiap variabel bebas (independent variabel) terhadap variabel terikatnya (dependent variabel) sebagai berikut ini

1. Nilai t-hitung untuk variabel sense sebesar $1,990>$ nilai $t$-tabel sebesar 1,966 dan nilai signifikannya sebesar 0,047 < alpha 0,05. Artinya, Ho ditolak dan Ha diterima. Dapat disimpulkan bahwa variabel sense secara parsial berpengaruh positif dan signifikan terhadap loyalitas konsumen store Berrybenka di Kota Jambi.

2. Nilai t-hitung untuk variabel feel sebesar $0,54<$ nilai $t$-tabel sebesar 1,966 dan nilai signifikannya sebesar 0,957 > alpha 0,05. Artinya Ho diterima dan Ha ditolak. Berdasarkan hasil yang diperoleh, berarti bahwa variabel feel secara parsial tidak berpengaruh positif dan tidak signifikan terhadap loyalitas konsumen store Berrybenka di Kota Jambi.

3. Nilai t- hitung untuk variabel think sebesar 2,301 nilai t-tabel sebesar 1,966 dan nilai signifikannya sebesar 0,022 < alpha 0,05. Artinya, Ha diterima dan Ho ditolak. Berdasarkan hasil yang diperoleh, berarti bahwa variabel think secara parsial 
berpengaruh positif dan signifikan terhadap loyalitas konsumen store Berrybenka di Kota Jambi.

4. Nilai t- hitung untuk variabel act sebesar 2,023 > nilai t-tabel sebesar 1,966 dan nilai signifikannya sebesar 0,044 < alpha 0,05. Artinya Ho ditolak dan Ha diterima. Berdasarkan hasil yang diperoleh, berarti bahwa variabel act secara parsial berpengaruh positif dan signifikan terhadap loyalitas konsumen store Berrybenka di Kota Jambi.

5. Nilai t- hitung untuk variabel relate sebesar 2,210 > nilai t-tabel sebesar 1,966 dan nilai signifikannya sebesar 0,028 < alpha 0,05. Artinya Ho ditolak dan Ha diterima. Berdasarkan hasil yang diperoleh, berarti bahwa variabel relate secara parsial berpengaruh positif dan signifikan terhadap loyalitas konsumen store Berrybenka di Kota Jambi.

Berdasarkan hasil pengujian secara parsial terhadap masing-masing variabel, maka yang memberikan pengaruh yang dominan terhadap loyalitas pelanggan adalah variabel Think $\left(\mathrm{X}_{3}\right)$ karena memiliki koefisien regresi yang lebih besar yaitu 0,109.

\section{Pengujian hipotesis secara simultan (uji f)}

Tabel 10

Hasil uji simultan (uji f)

ANOVA ${ }^{a}$

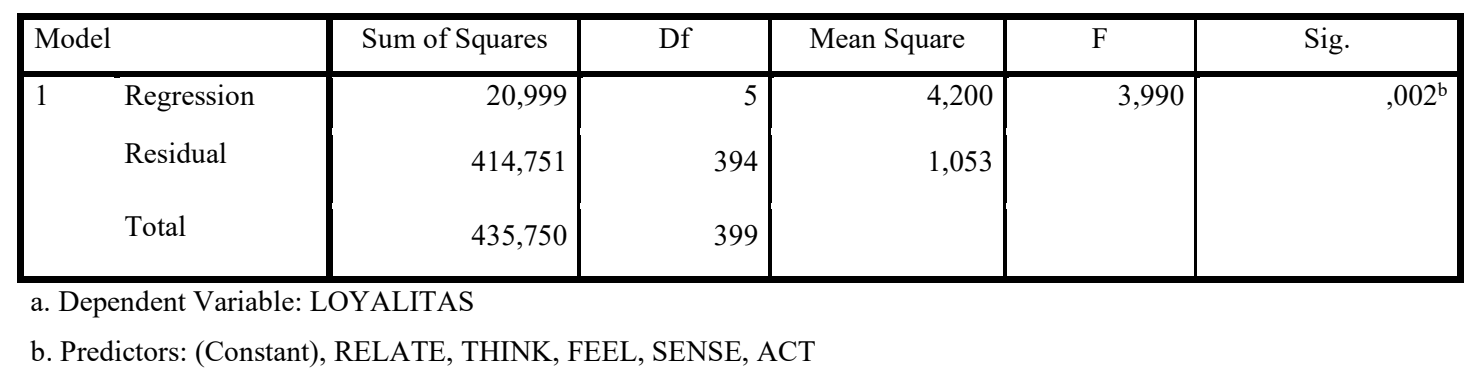

Sumber: Data diolah, 2021

Berdasarkan Tabel 10 diperoleh nilai F-hitung sebesar 3,990 dengan signifikasi 0,002, sedangkan $\mathrm{F}_{\text {-tabel }}$ pada tingkat kepercayaan (confidence interval) 95\% atau $\alpha=0,05$ adalah 2,28. Dengan membandingkan nilai F-hitung dengan F-tabel, maka F-hitung $(3,990)$ lebih besar dari F-tabel $(2,28)$. Artinya secara serempak variabel experiential marketing yang terdiri dari : sense, feel, think, act dan relate berpengaruh positif dan signifikan terhadap loyalitas pembelian di Store Berrybenka. 


\section{Uji $\mathbf{r}^{2}$ (koefesien determinasi)}

Hasil pengujian koefisien determinasi dengan menggunakan program analisis statistik SPSS dapat dilihat pada tabel 5.16 dibawah ini:

Tabel 11

Hasil uji $\mathbf{r}^{2}$ (koefisien determinasi)

\begin{tabular}{|l|r|r|r|r|}
\hline Model & \multicolumn{1}{|c|}{$\mathrm{R}$} & \multicolumn{1}{|c|}{ R Square } & \multicolumn{1}{c|}{$\begin{array}{c}\text { Adjusted R } \\
\text { Square }\end{array}$} & Std. Error of the Estimate \\
\hline 1 &, $480^{\mathrm{a}}$ &, 022 &, 036 & 1,02600 \\
\hline
\end{tabular}

a. Predictors: (Constant), RELATE, THINK, FEEL, SENSE, ACT

\section{Sumber : Data Diolah 2021}

Dari Tabel 11 terlihat bahwa nilai $R$ Square yang diperoleh adalah sebesar 0,480 atau 48\%. Ini menunjukkan bahwa variabel terikat (loyalitas) dapat dijelaskan oleh variabel bebas (sense, feel, think, act dan relate) sebesar 48\%, sedangkan sisanya sebesar 0,520 atau 52\% dijelaskan oleh variable bebas lainnya yang tidak diteliti dalam penelitian ini.

\section{KESIMPULAN DAN SARAN}

\section{Kesimpulan}

Berdasarkan hasil penelitian dan pembahasan yang telah diuraikan pada bab sebelumnya, maka dapat ditarik kesimpulan sebagai berikut:

1. Hasil pengujian hipotesis secara serempak (simultan) menunjukkan bahwa variabel experiential marketing yang terdiri dari : sense, feel, think, act dan relate berpengaruh positif dan signifikan terhadap loyalitas konsumen store Berrybenka di Kota Jambi, Hal ini berarti bahwa experiential marketing yang terdiri dari : sense, feel, think, act dan relate dapat memberikan kontribusi positif terhadap loyalitas konsumen store Berrybenka di Kota Jambi.

2. Hasil pengujian hipotesis secara parsial menunjukkan bahwa variabel experiential marketing yang terdiri dari : sense, think, act dan relate memberikan pengaruh yang positif dan signifikan terhadap loyalitas konsumen store Berrybenka di Kota Jambi sedangkan feel tidak berpengaruh signifikan terhadap loyalitas konsumen store Berrybenka di Kota Jambi.

3. Hasil pengujian hipotesis secara parsial menunjukkan bahwa think memberikan pengaruh yang dominan. Setiap bertambahnya pengetahuan konsumen terhadap store Berrybenka (limited edition, unik, kualitas baik) maka akan meningkatkan pembelian sebesar 10,9\%. 


\section{Saran}

Dari kesimpulan yang telah diuraikan diatas, maka peneliti memberikan saran-saran sebagai berikut:

1. Bagi Akademisi selanjutnya disarankan agar dapat menambah variabel bebas atau menggunakan variabel lain yang berpengaruh terhadap loyalitas pelanggan seperti : citra produk, kualitas produk, promosi dan sebagainya untuk diteliti pada masa yang akan datang. Serta dapat melakukan penelitian yang sama dengan menambahkan responden lebih banyak, karakterisistik responden yang lebih lengkap dan beragam latar belakangnya.

2. Bagi perusahaan Berrybenka diharapkan untuk lebih meningkatkan produk fashion nya dalam keunikan produk dan melengkapi model yang sangat kekinian sehingga menarik konsumen untuk berbelanja ke store Berrybenka.

3. Penelitian ini diharapkan dapat menjadi inspirasi mahasiswa lain yang akan melakukan penelitian serupa di waktu mendatang selain itu mampu memberikan kontribusi dalam memperluas pengetahuan masyarakat dalam bidang strategi pemasaran dan juga dapat menjadi bahan perbandingan atau menjadi referensi.

\section{DAFTAR PUSTAKA}

Arikunto, S. (2010). Metode peneltian. Jakarta: Rineka Cipta.

Ghozali, I. (2012). Aplikasi Analisis Multivariate dengan Program IBM SPSS 19, Badan Penerbit Universitas Diponegoro, Semarang. Diponegoro Journal Of Accounting.

Ibrahim, A. S. (2009). Metode Analisis Teks dan Wacana. Yogyakarta: Pustaka Pelajar.

Kotler, P., \& Keller, K. L. (2009). Manajemen Pemasaran, Jilid 1.Edisi 13. Jakarta: Erlangga, 14.

Lederman, N. G. (2006). Syntax of nature of science within inquiry and science instruction. In Scientific inquiry and nature of science (pp. 301-317). Springer, Dordrecht.

Schmitt, B. H. (1999). Experiential Marketing: How to Get Customers to Sense, Feel, Think, Act, and Relate to Your Company and Brands. New York: The Free Press.

Sugiyono (2016) . Memahami Penelitian Kualitatif. Bandung : Alfabeta.

Soleh, A., Marsyaf, A., \& Saputri, F. (2020). PENGARUH EXPERIENTIAL MARKETING TERHADAPLOYALITAS PENGGUNA SMARTPHONE SAMSUNG. Journal Development, 8(2), 141-151. 
Friedenberg, F. K., Hanlon, A., Vanar, V., Nehemia, D., Mekapati, J., Nelson, D. B., \& Richter, J. E. (2010). Trends in gastroesophageal reflux disease as measured by the National Ambulatory Medical Care Survey. Digestive diseases and sciences, 55(7), 1911-1917.

Stanton, W. J. (2012). Prinsip pemasaran, alih bahasa. Yohanes lamarto.

Hayati, F. N., Setiawati, B., \& Sumarni, I. (2021). PEGARUH HARGA DAN PROMOSI TERHADAP KEPUTUSAN PEMBELIAN PULSA PADA PELANGGAN NO-KIOS CELL KABUPATEN TABALONG. JAPB, 4(1), 416-425.

Sumintono, B., \& Widhiarso, W. (2014). Aplikasi model Rasch untuk penelitian ilmu-ilmu sosial (edisi revisi). Trim Komunikata Publishing House. 